\title{
Pengaruh Model Pembelajaran SFAE Bermediakan Mind Mapping Terhadap Kreativitas dan Kompetensi Pengetahuan IPA
}

\author{
Ni Putu Atika Dewi ${ }^{*}$, Luh Putu Putrini Mahadewi², Ni Ketut Desia Tristiantari ${ }^{3}$
}

123 Universitas Pendidiikan Ganesha, Singaraja, Indonesia

\begin{abstract}
Abstrak
Penelitian ini bertujuan untuk mengetahui pengaruh model pembelajaran Student Facilitator and Explaining bermediakan mind mapping terhadap kreativitas belajar dan kompetensi pengetahuan IPA. Penelitian ini merupakan penelitian quasi exsperiment dengan desain penelitian non equivalent post-test only control group. Populasi dalam penelitian ini seluruh siswa kelas V gugus VIII Kecamatan Tabanan berjumlah 72 orang siswa. Sampel dalam penelitian ini berjumlah 38 orang siswa dan dipilih dengan menggunakan teknik random sampling. Penilaaian unjuk kerja digunakan untuk mengumpulkan data kreativitas belajar dan tes pilihan ganda untuuk mengumpulkan data kompetensi pengetahuan IPA. Data hasil penelitian dianalisis dengan statistik deskriptif, uji-t, dan uji Manova. Hasil penelitian menunjukkan bahwa (1) terdapat pengaruh model pembelajaran Student Facilitator and Explaining bermediakan mind mapping terhadap kreativitas belajar siswa (nilai signifikansi $0,000<0,05)$, (2) terdapat pengaruh model pembelajaran Student Facilitator and Explaining bermediakan mind mapping terhadap kompetensi pengetahuan IPA siswa $(0,000<0,05)$, dan (3) secara simultan terdapat pengaruh model pembelajaran Student Facilitator and Explaining bermediakan mind mapping terhadap kreativitas belajar dan kompetensi pengetahuan IPA siswa $(0,00<0,05)$. Berdasarkan hasil penelitian dapat disimpulkan model pembelajaran Student Facilitator and Explaining bermediakan mind mapping berpengaruh terhadap kreativitas dan kompetensi pengetahuan IPA.

Kata Kunci:

IPA, kreativitas, mind mapping, SFAE
\end{abstract}

\begin{abstract}
This research aimed to find out the effect of Student Facilitator and Explaining learning model by using mind-mapping media towards students' learning creativity and IPA competency. This study was quasi experimental research which used nonequivalent post-test only control group design. The population of this research was fifth-grade of elementary students in Gugus VIII Tabanan with the total number were 72 students. 38 students were the sample of this study which was chosen by using random sampling technique. In this study, performance assessment was used to collect the data of students' creativity learning and multiple-choice test was used to collect the data of students'IPA competency. The result of the tests were analyzed by using descriptive statistic, t-test, and manova-test. The result showed that (1) there was an effect of Student Facilitator and Explaining learning model by using mindmapping media towards students' creativity of learning (significance value 0,000< 0,05), (2) there was an effect of Student Facilitator and Explaining learning modelby using mind-mapping media towards students' competency of IPA $(0,000<0,05)$, (3) there was an effect of Student Facilitator and Explaining learning model by using mind-mapping media towards students' creativity of learning and competency of IPA $(0,00<$ 0,05). Based on the result above, it can be concluded that Student Facilitator and Explaining learning model by using mind-mapping media was effective for students' creativity and competency of IPA.
\end{abstract}

\footnotetext{
* Corresponding author.

E-mail Addresses: - putu.atika.dewi@undiksha.ac.id (Ni Putu Atika Dewi)
} 


\section{PENDAHULUAN}

Ilmu Pengetahuan Alam (IPA) merupakan salah satu mata pelajaran yang dibelajarkan di sekolah dasar. IPA merupakan salah satu mata pelajaran yang pokok bahasannya tentang alam. Nash (dalam Samatowa, 2018) menyatakan bahwa "IPA itu adalah suatu cara atau metode untuk mengamati alam". Mata pelajaran IPA memberikan kesempatan pada siswa untuk berinteraksi secara langsung dengan alam dan isinya. Melalui pembelajaran IPA, siswa dapat mengetahui gejala-gejala yang ada di alam serta memberikan pemahaman yang lebih dalam tentang alam sekitar. Pembelajaran yang menggunakan alam atau lingkungan sebagai tempat belajar tentunya dapat meningkatkan minta belajar, memotivasi siswa, meningkatkan kreativitas, dan proses pembelajaran menyenangkan untuk siswa.

Pembelajaran IPA di sekolah dasar hendaknya dikemas dengan pembelajaran yang inovatif sehingga dapat mengembangkan kompetensi siswa. Kompetensi adalah pengintergrasian aspek pengetahuan, sikap, dan keterampilan untuk melakukan suatu tugas (Yaumi, 2018). Kompetensi siswa akan dapat berkembang apabila siswa dilibatkan secara aktif untuk membangun pengetahuannya sendiri dalam proses pembelajaran. Pengetahuan yang dibangun sendiri akan lebih mudah diingat dan dipahami siswa. Selain pengembangan kompetensi pengetahuan, kreativitas belajar siswa harus dikembangkan yang berperan dalam peningkatan prestasi siswa. Siswa yang memiliki kreativitas dalam belajar sudah pasti siswa tersebut berpikir secara kreatif. Siswa yang memiliki pemikiran kreatif akan mampu mencari berbagai solusi dalam menyelesaikan masalah dalam belajar. Berdasarkan hasil wawancara dengan guru kelas V di SD gugus VIII Kecamatan Tabanan ditemukan beberapa permasalahan diantaranya 1) penerapan model pembelajaran yang belum optimal, guru dominan menggunakan model pembelajaran konvensional (ceramah) dalam proses pembelajaran, 2) penggunaan media pembelajaran yang belum optimal karena guru mengalami kesulitan untuk membuat media pembelajaran yang cocok dan sesuai dengan materi pembelajaran, dan 3) pemahaman siswa terhadap materi IPA masih kurang hal ini ditunjukkan dari beberapa nilai ulangan harian siswa pada mata pelajaran IPA masih berada di bawah KKM.

Selain itu, dilakukan observasi saat proses pembelajaran IPA di kelas V, ditemukan beberapa permasalahan diantaranya 1) pada saat guru bertanya tentang materi pembelajaran hanya beberapa siswa yang mengacungkan tangan menjawab pertanyaan. Hal ini disebabkan kurangnya kreativitas belajar siswa dalam mengemukakan gagasan untuk menyelesaikan permasalahan dalam belajar, 2) siswa kurang mampu berpikir secara kreatif untuk menciptakan ide-ide baru dalam belajar, dan 3) guru masih menjadi pusat perhatian dalam proses pembelajaran yang mengakibatkan siswa kurang berpartisipasi aktif dalam belajar.

Proses pembelajaran yang dirancang dengan baik dapat mengembangkan kompetensi siswa salah satunya adalah kompetensi pengetahuan IPA. Adnyana (2017) menjelaskan kompetensi pengetahuan IPA adalah perubahan pada diri siswa melalui kegiatan pembelajaran sehingga menguasi materi pembelajaran IPA. Penguasan siswa terhadap materi pembelajaran IPA dapat menjadi tolak ukur pencapaian siswa dalam aspek pengetahuan. Laksmi (dalam Trianto, 2012) pembelajaran IPA di sekolah dasar memiliki tujuan adalah mengenalkan siswa tentang dunia tempat tinggal dan cara bersikap, menanamkan konsep tentang sikap ilmiah, mengajarkan keterampilan melakukan pengamatan, mengajarkan untuk mengenal dan menghargai para ilmuan penemu, dan menerapkan metode ilmiah dalam pemecahan masalah.

Merancang kegitan belajar dengan semenarik mungkin menunjang dalam pengembangan kreativitas siswa. Kreativitas adalah kemampuan untuk menghasilkan sesuatu yang baru, baik karya maupun gagasan yang berbeda dari yang sudah ada (Sormin, 2016). Seseorang yang kreatif memiliki pemikiran yang terbuka sehingga dapat mencari solusi maupun jawaban yang berbeda dari orang lain untuk menyelesaikan permasalah yang dihadapi. Kreativitas dapat dikembangkan dengan melakuka halhal yang kreatif. Sani (2015) menyatakan kreativitas dapat dikembangkan dalam diri siswa dengan cara: 1) mengembangkan imajinasi, 2) menghasilkan sesuatu atau gagasan yang baru, 3) kegiatan produktif, 4) memecahkan suatu permasalahan, dan 5) menghasilkan sesuatu yang benilai guna.

Penerapan model pembelajaran inovatif dalam proses pembelajaran memberikan siswa kesempatan untuk mengggali dan membangun pengetahuan sendiri yang mudah dipahami sehingga pembelajaran bermakna untuk siswa. Salah satu model pembelajaran inovatif yang dapat diterapkan adalah model pembelajaran Student Facilitator and Explaining bermediakan mind mapping. Kurniasih dan Sani (2015) menyatakan model pembelajaran Student Facilitator and Explaining adalah suatu model yang memberikan siswa kesempatan untuk belajar menyajikan ide atau pendapat kepada temantemannya. Model pembelajaran Student Facilitator and Explaining melatih kepercayaan diri, meningkatkan partisipasi siswa dalam proses pembelajaran, dan meningkatkan pemahaman siswa karena siswa dapat menggunakan kata-kata sendiri dalam penyampaian materi sehingga lebih mudah untuk diingat. 
Adapun langkah-langkah model pembelajaran Student Facilitator and Explaining adalah 1) menyampaikan materi dan kompetensi dasar pembelajaran, 2) guru menjelaskan garis-garis besar materi pembelajaran, 3) guru memberikan kesempatan kepada siswa untuk menyajikan materi atau pendapat secara bergilir, 4) menyimpulkan materi, ide, atau pendapat yang telah disampaikan siswa, 5) guru menjelaskan semua materi pembelajaran, dan 6) penutup (Shoimin, 2017). Kelebihan dari model pembelajaran Student Facilitator and Explaining adalah 1) materi yang jelas, 2) meningkatkan daya serap siswa karena pembelajaran menggunakan demostrasi, 3) siswa dilatih menjadi guru serta facilitator dalam kegiatan pembelajaran, 4) motivasi siswa menjadi yang terbaik menyajikan materi, dan 5) mengetahui kemampuan siswa dalam menyampaikan ide maupun pendapatnya (Shoimin, 2017).

Penerapan model pembelajaran Student Facilitator and Explaining dapat didukung dengan penggunaan media pembelajaran agar proses pembelajaran berjalan lebih optimal, salah satunnya menggunakan media mind mapping. Windura (dalam Santi, 2017) menjelaskan mind mapping adalah cara mencatat dengan mengaplikasikan warna, simbol, gambar, dan kata-kata kunci yang memudahkan untuk mengingat materi maupun informasi. Adapun kelebihan mind mapping adalah 1) meningkatkan pengetahuan, 2) memaksimalkan kerja otak, 3) dapat menyajikan ide atau informasi lebih banyak, 4) mengembangkan kreativitas, dan 5) dapat mengingat informasi dengan lebih mudah (Swadarma, 2013).

Mencatat dengan mengaplikasikan warna serta gambar akan menyenangkan bagi siswa dibandingkan dengan mencatat materi hanya menggunakan kata-kata karena melibatkan imajinasi siswa. Belajar dengan menggunakan mind mapping akan mempermudah siswa mengingat lebih banyak materi pembelajaran, menjadikan pembelajaran tidak membosankan, meningkatkann kreativitas, serta menigkatkan pemahaman terhadap materi pembelajaran.

\section{METODE PENELITIAN}

Jenis penelitian ini adalah quasi eksperimen dengan desain non equivalent post-test only control group karena penelitian ini memberikan post-test setelah diberikan penerapan model pembelajaran Student Facilitator and Explaining bermedikan mind mapping. Populasi dalam penelitian ini adalah seluruh siswa kelas V di gugus VIII Kecamatan Tabanan tahun 2018/2019 yang terdiri dari lima kelas. Jumlah siswa kelas V adalah sebanyak 72 siswa. Pada penelitian ini dilakukan penentuan sampel penelitian sebelum dilaksanakannya penelitian. Sampel merupakan sebagian dari populasi yang dianggap mewakili dari populasi yang ada (Agung, 2014). Teknik yang digunakan dalam pengambilan sampel dari populasi adalah random sampling. Sebelum memilih kelas yang akan dijadikan sampel penelitian terlebih dahulu dilakukan uji kesetaraan kompetensi pengetahuan siswa kelas V gugus VIII Kecamatan Tabanan dengan menggunakan nilai ulangan akhir semester siswa untuk mengetahui apakah seluruh siswa kelas $\mathrm{V}$ memiliki kemampuan yang sama. Uji homogenitas menggunakan ANAVA satu jalur dengan menggunakan bantuan SPSS Statistics 21 for Windows.

Berdasarkan hasil uji kesetaraan yang telah dilakukan, nilai signifikansi mendapatkan 0,231 > dari 0,05, artinya tidak terdapat perbedaan kompetensi pengetahuan IPA siswa kelas V. Hal ini menunjukkan bahwa seluruh siswa kelas V gugus VIII Kecamatan Tabanan memiliki kompetensi pengetahuan yang homogen atau sama. Setelah dilakukan uji kesetaraan, selajutnya penentuan anggota sampel dengan pengundian. Hasil pengundian yang telah dilakukan diperoleh kelas V SD Negeri 3 Sudimara sebagai kelas eksperimen dan siswa kelas V SD Negeri 2 Sudimara sebagai kelas kontrol.

Metode yang digunakan dalam penelitian ini adalah metode tes dan non-tes. Metode tes berupa tes pilihan ganda digunakan untuk mengumpulkan data kompetensi pengetahuan IPA. Sedangkan metode non-tes berupa penilaian unjuk kerja digunakan untuk mengumpulkan data kreativitas belajar. Instrumen tes pilihan ganda dan penilaian unjuk kerja sebelumnya dilakukan uji coba. Adapun pengujian yang dilakukan: (1) uji validitas isi, (2) uji validitas butir, (3) uji reliabilitas, (4) uji tingkat taraf kesukaran, dan (5) uji daya beda tes.

Teknik analisis data yang digunakan adalah analisis statistik deskriptif dengan mencari mean, median, modus, dan stadar deviasi. Uji hipotesis dilakukan dengan mengguakan uji-t dan uji manova. Sebelum melakukan uji hipotesis diawali dengan melakukan uji prayarat analisis meliputi uji normalitas, uji homogenitas, dan uji korelasi antar variabel terikat

\section{ANALISIS DAN PEMBAHASAN}

Data post-test kreativitas belajar dan kompetensi pengetahuan IPA kelompok eksperimen dan kelompok kontrol dianalisis dengan statistik deskriptif. Rangkuman statistik deskriptif variabel penelitian disajikan pada Tabel 1. 
Tabel 1. Rangkuman statistik deskriptif data variabel penelitian

\begin{tabular}{|c|c|c|c|c|}
\hline \multirow[t]{3}{*}{ Statistik } & \multicolumn{2}{|c|}{ Kelompok Eksperimen } & \multicolumn{2}{|l|}{ Kelompok Kontrol } \\
\hline & Kreativitas & Kompetensi & Kreativitas Belajar & Kompetensi \\
\hline & Belajar & Pengetahuan IPA & & Pengetahuan IPA \\
\hline $\mathrm{N}$ & 18 & 18 & 20 & 20 \\
\hline Mean & 81,5 & 80,72 & 72,95 & 69,1 \\
\hline Median & 83,5 & 81,64 & 72,62 & 67 \\
\hline Modus & 87,5 & 81,2 & 74,82 & 68,19 \\
\hline Standar Deviasi & 6,09 & 6,48 & 4,97 & 7,86 \\
\hline Minimum & 70 & 70 & 64 & 50 \\
\hline Maksimum & 89 & 93 & 84 & 83 \\
\hline
\end{tabular}

Rata-rata nilai kreativitas belajar dan kompetensi pengetahuan IPA siswa kedua kelompok kemudian dikonversikan ke dalam kategori pada skala lima dengan menggunakan kriteria rata-rata ideal $\left(\mathrm{M}_{\mathrm{i}}\right)$ dan standar deviasi ideal $\left(\mathrm{SD}_{\mathrm{i}}\right)$. Kategori pada skala lima data kreativitas belajar dan kompetensi pengetahuan IPA siswa yang dibelajarkan dengan model pembelajaran Student Facilitator and Explaining bermediakan mind mapping disajikan pada Tabel 2.

Tabel 2 Kategori skala lima data kreativitas belajar dan kompetensi pengetahuan ipa

\begin{tabular}{ll}
\hline Rentangan Nilai & Klasifikasi \\
\hline $75 \leq \overline{\mathrm{X}} \leq 100$ & Sangat tinggi \\
$58 \leq \overline{\mathrm{X}} \leq 75$ & Tinggi \\
$42 \leq \overline{\mathrm{X}} \leq 58$ & Sedang \\
$25 \leq \overline{\mathrm{X}} \leq 42$ & Rendah \\
$0 \leq \overline{\mathrm{X}} \leq 42$ & Sangat rendah \\
\hline
\end{tabular}

Berdasarkan hasil konversi pada Tabel 2, rata-rata nilai kreativitas belajar kelompok eksperimen adalah 81,5 berada pada kategori sangat tinggi. Rata-rata nilai kreativitas belajar kelompok kontrol adalah 72,95 berada pada kategori tinggi. Rata-rata nilai kompetensi pengetahuan IPA kelompok eksperimen adalah 80,72 berada pada katogeri sangat tinggi. Rata-rata nilai kompetensi pengetahuan IPA kelompok kontrol adalah 69,1 berada pada kategori tinggi. Data post-test kreativitas belajar kelompok eksperimen disajikan dalam bentuk histogram pada Gambar 1.

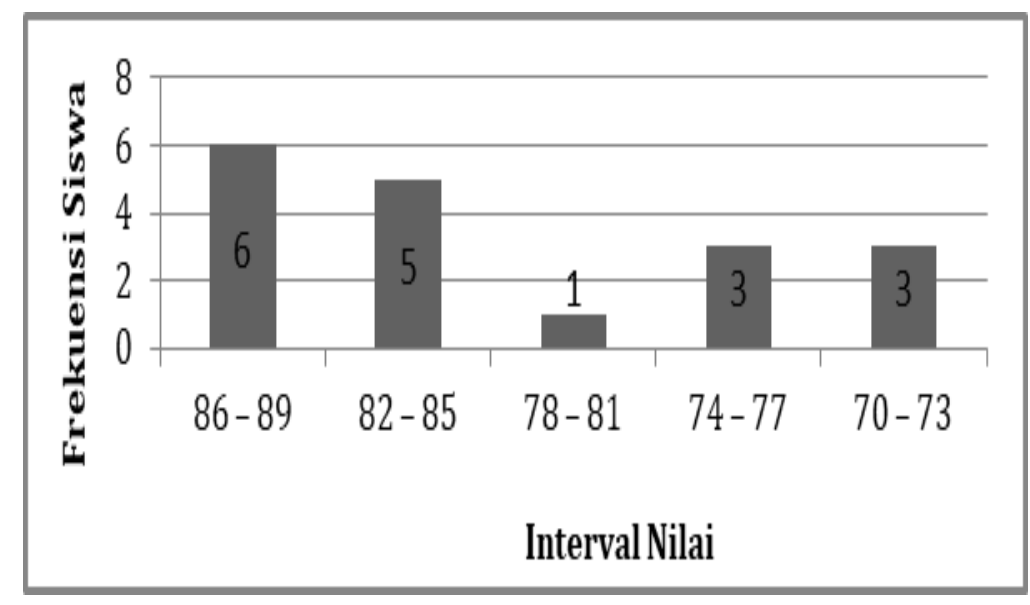

Gambar 1. Data kreativitas belajar kelompok eksperimen

Berdasarkan histogram pada Gambar 1, diketahui bahwa siswa yang mendapat nilai pada interval 86 - 89 sebanyak 6 orang, siswa yang mendapat nilai pada interval 82 - 85 sebanyak 5 orang, siswa yang mendapat nilai pada interval $78-81$ sebanyak 1 orang, siswa yang mendapat nilai pada interval $74-77$ 
sebanyak 3 orang, dan siswa yang mendapat nilai pada interval $70-73$ adalah 3 orang. Data kompetensi pengetahuan IPA kelompok eksperimen disajikan dalam bentuk histogram pada Gambar 2.

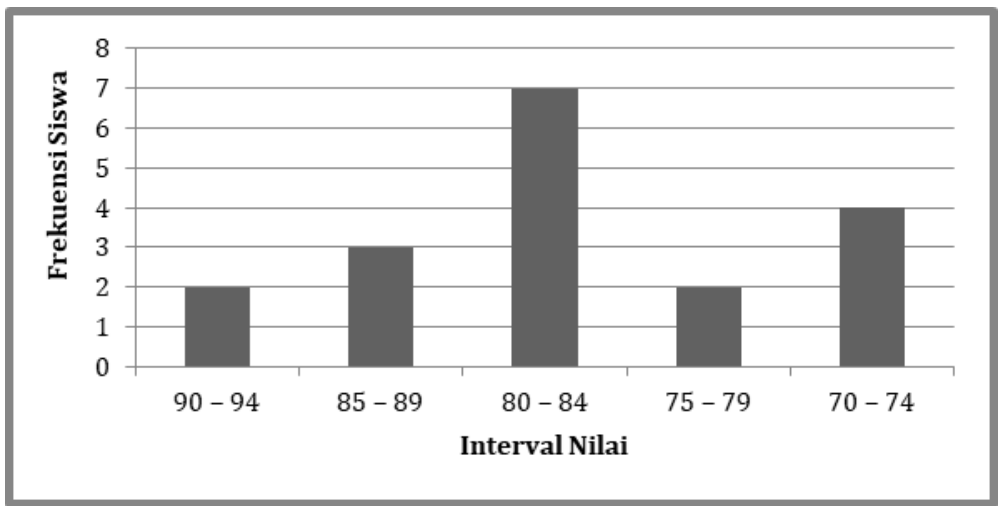

Gambar 2. Histogram data kompetensi pengetahuan IPA kelompok eksperimen

Berdasarkan histogram data kompetensi pengetahuan IPA kelas eksperimen, diketahui bahwa siswa yang mendapat nilai pada interval 90 - 94 sebanyak 2 orang, siswa yang mendapat nilai pada interval 85 - 89 sebanyak 3 orang, siswa yang menadapat nilai pada interval 80 - 84 sebanyak 7 orang, siswa yang mendapat nilai pada interval 75 - 79 sebanyak 2 orang, dan siswa yang mendapat nilai pada interval 70 - 74 adalah 4 orang. Data post-test kreativitas belajar kelompok kontrol disajikan dalam bentuk histogram pada Gambar 3.

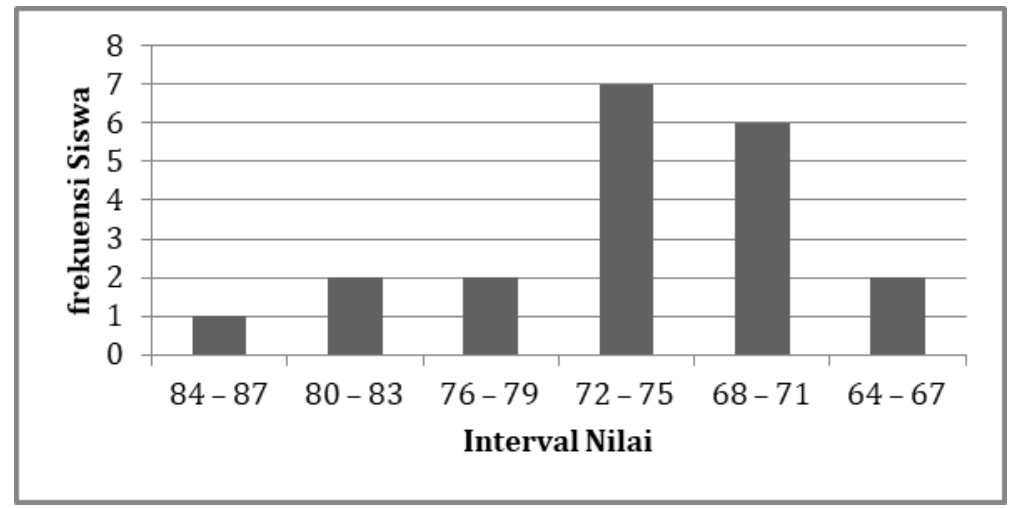

Gambar 3. Histogram data kreativitas belajar kelompok Kontrol

Berdasarkan histogram pada Gambar 3, diketahui bahwa siswa yang mendapat nilai pada interva 84 - 87 sebanyak 1 orang, siswa yang mendapat nilai pada interva $80-83$ sebanyak 2 orang, siswa yang mendapat nilai pada interva $76-79$ sebanyak 2 orang, siswa yang mendapat nilai pada interva $72-75$ sebanyak 7 orang, siswa yang mendapat nilai pada interva 68 - 71 sebanyak 6 orang, dan siswa yang mendapat nilai pada interva 64 - 67 sebanyak 2 orang. Data post-test kompetensi pengetahuan IPA kelompok kontrol disajikan dalam bentuk histogram pada Gambar 4. 


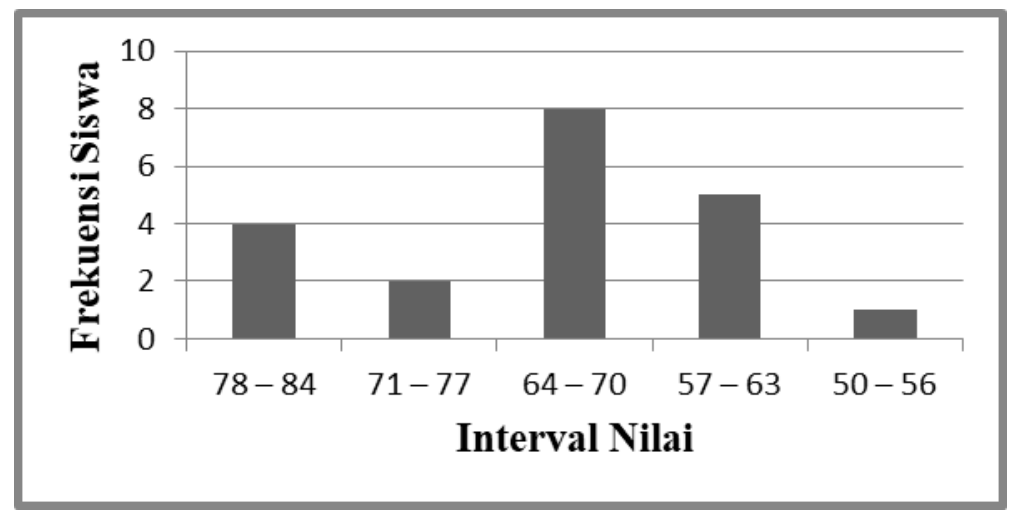

Gambar 4. Histogram data kompetensi pengetahuan IPA kelompok kontrol

Berdasarkan histogram data kompetensi pengetahuan IPA kelompok kontrol diketahui bahwa siswa yang mendapat nilai antara 78 - 84 sebanyak 4 orang, siswa yang mendapat nilai antara $71-77$ sebanyak 2 orang, siswa yang mendapat nilai antara 64 - 70 sebanyak 8 orang, siswa yang mendapat nilai antara 57 - 63 sebanyak 5 orang, dan siswa yang mendapat nilai antara $50-56$ adalah 1 orang.

Data post-test kreativitas belajar dan kompetensi pengetahuan IPA kedua kelompok yang telah terkumpul dilakukan pengujian hipotesis menggunakan uji-t dan uji manova dibantu dengan program SPSS Statistics 21 for Windows. Untuk menggunakan uji-t dan uji manova data hasil penelitian harus memenuhi prasyarat analisis dengan melakukan uji normalitas, uji homogenitas, dan uji korelasi antar varibel terikat.

Uji normalitas dilakukan untuk mengetahui data hasil penelitian yang didapatkan berdistribusi normal atau tidak. Apabila data berdistribusi normal maka dapat dilanjutkan dengan pengujian hipotesis. Uji normalitas dilakukan dengan menggunakan uji kolmogorof-smirnof dibantu dengan program SPSS Statistic 21 for Windows. Kriteria pengujian data hasil penelitian adalah jika nilai signifikansi yang dihasilkan lebih besar dari 0,05 maka data dinyatakan berdistribusi normal. Hasil uji normalitas dengan uji kolmogorof-smirnof dibantu dengan menggunakan program SPSS Statistic 21 for Windows dapat dilihat pada Tabel 3.

Tabel 3. Hasil uji normalitas menggunakan uji kolmogorof-smirnov

\begin{tabular}{llllllll}
\hline & Kelompok & \multicolumn{2}{l}{ Kolmogorov-Smirnov $^{\mathrm{a}}$} & \multicolumn{3}{c}{ Shapiro-Wilk } \\
& & Statistic & Df & Sig. & Statistic & df & Sig. \\
\hline \multirow{2}{*}{ Kreativitas Belajar } & Eksperimen & .155 & 18 & $.200^{*}$ & .912 & 18 & .095 \\
& Kontrol & .118 & 20 & $.200^{*}$ & .975 & 20 & .849 \\
Kompetensi & Eksperimen & .123 & 18 & $.200^{*}$ & .962 & 18 & .650 \\
Pengetahuan IPA & Kontrol & .156 & 20 & $.200^{*}$ & .949 & 20 & .356 \\
\hline
\end{tabular}

Berdasarkan hasil uji normalitas sebaran data dengan uji kolmogorof-smirnof pada tabel 3, didapatkan nilai signifikansi data kreativitas belajar siswa kelompok eksperimen, data kompetensi pengetahuan IPA siswa kelompok eksperimen, data kreativitas belajar siswa kelompok kontrol, dan data kompetensi pengetahuan IPA siswa kelompok kontrol lebih besar dari 0,05 hal ini berarti keseluruhan data berdistribusi normal.

Uji homogenitas varians dilakukan untuk mengetahui data dari kelompok eksperimen dan kontrol memiliki varians yang sama atau homogen. Uji homogenitas dilakukan menggunakan uji fisher (uji F) dibantu dengan program SPSS Statistic 21 for Windows. Kriteria pengujian data adalah jika nilai signifikansi lebih besar dari 0,05 maka data kreativitas belajar dan kompetensi pengetahuan IPA dari kedua kelompok sampel dinyatakan memiliki varians yang sama atau homogen. Hasil uji homogenitas kedua kelompok data dapat dilihat pada Tabel 4.

Tabel 4. Hasil homogenitas varians dibantu dengan program SPSS Statistic 21 For Windows

\begin{tabular}{lllll}
\hline & F & df1 & df2 & Sig. \\
\hline Kreativitas Belajar & 1.700 & 1 & 36 & .201 \\
Kompetensi Pengetahuan IPA & .237 & 1 & 36 & .630 \\
\hline
\end{tabular}


Berdasarkan hasil uji homogenitas menggunakan SPSS Statistic 21 for Windows pada tabel 4, didapatkan hasil bahwa nilai signifikansi data kreativitas belajar dan kompetensi pengetahuan IPA kedua kelompok sampel lebih besar dari 0,05. Hal ini berarti data kreativitas belajar dan kompetensi pengetahuan IPA kedua kelompok data memiliki varians yang sama atau homogen.

Uji korelasi antar variabel terikat kelompok eksperimen dan kelompok kontrol dianalisis dengan menggunakan bantuan program SPSS Statistic 21 for Windows. Kriteria pengujian yaitu jika nilai signifikansi data hasil penelitian lebih besar dari 0,05 maka kedua variabel tidak memiliki korelasi yang signifikan. Hasil uji korelasi antar variabel terikat kelompok eksperimen dan kelompok kontrol dapat dilihat pada Tabel 5 dan Tabel 6.

Tabel 5. Hasil uji korelasi antar variabel terikat kelompok eksperimen

\begin{tabular}{lllc}
\hline & & Kreativitas Belajar & Kompetensi Pengetahuan IPA \\
\hline Kreativitas Belajar & Pearson Correlation & 1 & .249 \\
& Sig. (2-tailed) & & .318 \\
& $\mathrm{~N}$ & 18 & 18 \\
Kompetensi & Pearson Correlation & .249 & 1 \\
Pengetahan IPA & Sig. (2-tailed) & .318 & \\
& $\mathrm{~N}$ & 18 & 18 \\
\hline
\end{tabular}

Tabel 6. Hasil uji korelasi antar variabel terikat kelompok control

\begin{tabular}{lllc}
\hline & & Kreativitas Belajar & Kompetensi Pengetahuan IPA \\
\hline \multirow{2}{*}{ Kreativitas Belajar } & Pearson Correlation & 1 & .326 \\
& Sig. (2-tailed) & & .160 \\
& N & 20 & 20 \\
Kompetensi & Pearson Correlation & .326 & 1 \\
Pengetahuan IPA & Sig. (2-tailed) & .160 & \\
& N & 20 & 20 \\
\hline
\end{tabular}

Berdasarkan hasil uji korelasi antar variabel terikat pada tabel 5 dan tabel 6, diketahui bahwa nilai signifikansi 2-tailed variabel kreativitas belajar dan kompetensi pengetahuan IPA kelompok eksperimen adalah 0,318. Sedangkan nilai signifikansi 2-tailed variabel kreativitas belajar dan kompetensi pengetahuan IPA kelompok kontrol adalah 0,160. Nilai signifikansi variabel kedua kelompok sampel lebih besar dari 0,05 dapat disimpulkan bahwa tidak terdapat korelasi atau hubungan yang signifikan. Hal ini menunjukkan tidak terdapat aspek yang sama yang diukur pada variabel-variabel terikat dan uji hipotesis dapat dilakukan.

Hipotesis pertama dianalisis menggunakan uji-t dibantu dengan menggunakan program SPSS Statistic 21 for Windows. Kriteria pengujian hipotesis pertama adalah jika nilai signifikansi yang dihasilkan lebih kecil dari 0,05 maka $\mathrm{H}_{0}$ ditolak dan $\mathrm{H}_{1}$ diterima. Hasil analisis hipotesis pertama dapat dilihat pada Tabel 7.

Tabel 7. Hasil analisis hipotesis pertama menggunakan uji-t dibantu SPSS Statistics 21 for Window

\begin{tabular}{|c|c|c|c|c|c|c|}
\hline & & \multicolumn{2}{|c|}{$\begin{array}{l}\text { Levene's Test for Equality of } \\
\text { Variances }\end{array}$} & \multicolumn{2}{|c|}{$\begin{array}{l}\text { t-test for Equality } \\
\text { of Means }\end{array}$} & \multirow[b]{2}{*}{ Sig. (2-tailed) } \\
\hline & & $\mathrm{F}$ & Sig. & $\mathrm{T}$ & $\mathrm{df}$ & \\
\hline \multirow[t]{2}{*}{$\begin{array}{l}\text { Kreativitas } \\
\text { Belajar }\end{array}$} & $\begin{array}{ll}\text { Equal } & \text { variances } \\
\text { assumed } & \end{array}$ & 1.700 & .201 & 4.629 & 36 & .000 \\
\hline & $\begin{array}{l}\text { Equal variances not } \\
\text { assumed }\end{array}$ & & & 4.579 & 32.862 & .000 \\
\hline
\end{tabular}

Berdasarkan hasil analisis hipotesis pertama pada tabel 7, diperoleh nilai sig (2-tailed) sebesar 0,000 lebih kecil dari 0,05 $(0,000<0,05)$ maka $\mathrm{H}_{0}$ ditolak dan $\mathrm{H}_{1}$ diterima. Sehingga analisis uji hipotesis pertama dapat disimpulkan bahwa terdapat pengaruh yang signifikan model pembelajaran Student 
Fasilitator and Explaining bermediakan mind mapping terhadap kreativitas belajar siswa kelas V gugus VIII Kecamatan Tabanan tahun 2018/2019.

Hipotesis kedua dianalisis menggunakan uji-t dibantu dengan menggunakan program SPSS Statistic 21 for Windows. Kriteria pengujian hipotesis kedua adalah jika nilai signifikansi yang dihasilkan lebih kecil dari 0,05 maka $\mathrm{H}_{0}$ ditolak dan $\mathrm{H}_{1}$ diterima, artinya terdapat pengaruh yang signifikan model pembelajaran Student Facilitator and Explaining bermediaka mind mapping terhadap kompetensi pengetahuan IPA siswa kelas V gugus VIII Kecamatan Tabana tahun 2018/2019. Hasil analisis hipotesis kedua dapat dilihat pada Tabel 8 .

Tabel 8. Hasil analisis hipotesis kedua menggunakan uji-t dibantu SPSS Statistics 21 for Windows

\begin{tabular}{|c|c|c|c|c|c|c|}
\hline & $\begin{array}{l}\text { Levene's Test } \\
\text { Equality of Variances }\end{array}$ & \multicolumn{2}{|c|}{$\begin{array}{l}\text { for t-test for Equality } \\
\text { of Means }\end{array}$} & \multirow{2}{*}{$\begin{array}{l} \\
\text { Sig. } \\
\text { tailed) }\end{array}$} & \\
\hline & & F $\quad$ Sig. & $\mathrm{T}$ & df & & (2- \\
\hline Kompetensi & Equal variances assumed & .630 & 4.817 & 36 & .000 & \\
\hline $\begin{array}{l}\text { Pengetahuan } \\
\text { IPA }\end{array}$ & $\begin{array}{l}\text { Equal variances not } \\
\text { assumed }\end{array}$ & & 4.867 & $\begin{array}{l}35.74 \\
0\end{array}$ & .000 & \\
\hline
\end{tabular}

Berdasarkan hasil analisis hipotesis kedua pada tabel 8, diperoleh nilai sig (2-tailed) sebesar 0,000 lebih kecil dari $0,05(0,000<0,05)$ maka $\mathrm{H}_{0}$ ditolak dan $\mathrm{H}_{1}$ diterima. Sehingga analisis uji hipotesis pertama dapat disimpulkan bahwa terdapat pengaruh yang signifikan model pembelajaran Student Facilitator and Explaining bermediaka mind mapping terhadap kompetensi pengetahuan IPA siswa kelas $\mathrm{V}$.

Hipotesis ketiga dianalisis menggunakan uji manova dibantu dengan menggunakan program SPSS Statistic 21 for Windows. Kriteria pengujian hipotesis ketiga adalah jika nilai signifikansi untuk Pillae Trace, Wilk Lambda, Hotelling Trace, Roy's Largest Root memiliki signifikansi kurang dari 0,05 maka $\mathrm{H}_{0}$ ditolak dan $\mathrm{H}_{1}$ diterima. analisis hipotesis ketiga menggunakan Uji Manova dilihat pada Tabel 9.

Tabel 9. Ringkasan analisis hipotesis ketiga menggunakan uji manova

\begin{tabular}{lllllll}
\hline Effect & & Value & F & Hypothesis df & Error df & Sig. \\
\hline \multirow{5}{*}{ Intercept } & Pillai's Trace & .996 & $4176.863^{\mathrm{b}}$ & 2.000 & 35.000 & .000 \\
& Wilks' Lambda & .004 & $4176.863^{\mathrm{b}}$ & 2.000 & 35.000 & .000 \\
& Hotelling's Trace & 238.678 & $4176.863^{\mathrm{b}}$ & 2.000 & 35.000 & .000 \\
& Roy's Largest Root & 238.678 & $4176.863^{\mathrm{b}}$ & 2.000 & 35.000 & .000 \\
& Pillai's Trace & .491 & $16.903^{\mathrm{b}}$ & 2.000 & 35.000 & .000 \\
\multirow{3}{*}{ Kelompok } & Wilks' Lambda & .509 & $16.903^{\mathrm{b}}$ & 2.000 & 35.000 & .000 \\
& Hotelling's Trace & .966 & $16.903^{\mathrm{b}}$ & 2.000 & 35.000 & .000 \\
& Roy's Largest Root & .966 & $16.903^{\mathrm{b}}$ & 2.000 & 35.000 & .000 \\
\hline
\end{tabular}

Berdasarkan hasil analisis hipotesis ketiga pada tabel 9, didapatkan nilai signifikansi untuk Pillae Trace, Wilk Lambda, Hotelling Trace, Roy's Largest Root 0,000 lebih kecil dari 0,05 maka $\mathrm{H}_{0}$ ditolak dan $\mathrm{H}_{1}$ diterima. Jadi hasil analisis hipotesis ketiga dapat disimpulkan bahwa secara simultan terdapat pengaruh model pembelajaran Student Facilitator and Explaining bermediakan mind mapping terhadap kreativitas belajar dan kompetensi pengetahuan IPA siswa kelas V.

Penerapan model pembelajaran Student Facilitator and Explaining bermediakan mind mapping di kelas eksperimen membuat proses pembelajaran berpusat pada siswa, siswa dapat berpikir secara kreatif dalam mengungkapkan pendapat saat menjawab pertanyaan yang diajukan oleh guru maupun pertanyaan yang diajukan teman. Kegiatan menyampaikan pendapat membuat siswa dapat saling bertukar pikiran atau informasi dengan temannya, sehingga siswa memiliki pemikiran terbuka untuk menerima informasi yang berbeda. Selaras dengan pendapat Delianti (2018) menyatakan model pembelajaran Student Facilitator and Explaining siswa dilatih untuk menjadi fasilitator dan berpikir kreatif untuk melibatkan siswa dalam pembelajaran aktif dan menyenangkan.

Penerapan model pembelajaran Student Facilitator and Explaining didukung dengan penggunaan media mind mapping, siswa mengembangkan daya imajinasinya menyajikan materi maupun ide-ide dengan menuangkan dalam bentuk catatan kreatif dengan memetakan pikiran siswa, sehingga membuat 
proses pembelajaran menjadi menyenangkan bagi siswa. Berdasarkan pemaparan dapat disimpulkan model pembelajaran Student Facilitator and Explaining bermediakan mind mapping berpengaruh terhadap kreativitas belajar siswa.

Model pembelajaran Student Facilitator and Explaining bermediakan mind mapping yang diterapkan di kelas eksperimen memberikan pengaruh positif. Siswa yang dibelajarkan dengan model pembelajaran Student Facilitator and Explaining bermediakan mind mapping lebih percaya diri mengemukakan gagasan dan siswa dilibatkan secara aktif dalam pembelajaran. Kegiatan menyampaikan pendapat membuat siswa mampu menganalisis serta menyimpulkan sendiri dengan pemahaman mereka sendiri konsep dalam pembelajaran yang membuat pembelajaran lebih bermakna bagi siswa. Siswa lebih mudah mengingat dan memahami materi karena siswa menggunakan kata-katanya sendiri dalam penyampaian materi. Siswa lebih berani berbicara di depan anggota kelas dan membiasakan menggali informasi sendiri yang cenderung dapat diingat lebih lama serta siswa lebih bertanggung jawab terhadap tugas yang diberikan.

Selain itu, penggunaan media mind mapping merangsang siswa lebih antusias dalam proses pembelajaran. Media mind mapping memudahkan siswa mengingat materi pembelajaran karena siswa mencatat materi pembelajaran dengan mengaplikasikan gambar dan simbol yang menarik. Berdasarkan pemaparan dapat disimpulkan bahwa model pembelajaran Student Facilitator and Explaining bermediakan mind mapping berpengaruh terhadap kompetensi pengetahuan siswa.

Model pembelajaran Student Facilitator and Explaining bermediakan mind mapping yang diterapkan di kelas eksperimen, siswa terlihat aktif menggali pengetahuannya sendiri untuk menenukan konsep-konsep pembelajaran dan bukan dalam bentuk hafalan sehingga memberikan pengalaman belajar yang bermakna bagi siswa. Siswa diberikan kesempatan untuk membangun pengetahuannya sendiri yang dapat diingat dan dipahami lebih lama yang berpengaruh terhadap perkembangan kompetensi IPA siswa. Selain itu, siswa kreatif dalam mengungkapkan ide maupun pendapat untuk memecahkan permasalahan dalam belajar seperti menjawab berbagai pertanyaan yang diajukan. Berdasarkan hasil pemaparan dapat disimpulkan secara simultan terdapat pengaruh yang signifikan model Pembelajaran Student Facilitatior and Explaining bermediakan mind mapping terhadap kreativitas belajar dan kompetensi pengetahuan IPA siswa.

\section{KESIMPULAN} berikut.

Berdasarkan hasil analisis dan pembahasan, maka simpulan dari penelitian ini adalah sebagai

1. Terdapat pengaruh yang signifikan model pembelajaran Student Facilitator and Explaining bermediakan mind mapping terhadap kreativitas belajar siswa kelas V. Hasil uji hipotesis diperoleh dengan menggunaka uji-t mendapat nilai signifikansi sebesar 0,000 lebih kecil dari 0,05 $(0,000<$ 0,05). Rata-rata nilai kreativitas belajar siswa kelompok eksperimen sebesar 81,5 lebih tinggi dibandingkan dengan kelas kontrol sebesar 72,95. Sehingga dapat disimpulkan model pembelajaran Student Facilitator and Explaining bermediakan mind mapping berpengaruh terhadap kreativitas belajar siswa.

2. Terdapat pengaruh yang signifikan model pembelajaran Student Facilitator and Explaining bermediakan mind mapping terhadap kompetensi pengetahuan IPA siswa kelas V. Hasil uji hipotesis diperoleh dengan menggunaka uji-t mendapat nilai signifikansi sebesar 0,000 lebih kecil dari 0,05 $(0,000<0,05)$. Rata-rata nilai kompetensi pengetahuan IPA siswa kelompok eksperimen sebesar 80,72 lebih tinggi dibandingkan dengan kelas kontrol sebesar 69,1. Sehingga dapat disimpulkan model pembelajaran Student Facilitator and Explaining bermediakan mind mapping berpengaruh terhadap kompetensi pengetahuan IPA siswa.

3. Secara simultan terdapat pengaruh yang signifikan model pembelajaran Student Facilitator and Explaining bermediakan mind mapping terhadap kreativitas belajar dan kompetensi pengetahuan IPA siswa kelas V. Hasil uji hipotesis menggunakan uji manova diperoleh nilai signifikansi untuk Pillae Trace, Wilk Lambda, Hotelling Trace, Roy's Largest Root 0,000 kurang dari 0,05 $(0,000<$ $0,05)$, sehingga dapat disimpulkan secara simultan model pembelajaran Student Facilitator and Explaining bermediakan mind mapping berpengaruh terhadap kreativitas belajar dan kompetensi pengetahuan IPA siswa.

Saran yang dapat disampaikan untuk menunjang peningkatan kualitas pembelajaran adalah sebagai berikut: 1) Siswa lebih berpartisipasi aktif dalam proses pembelajaran sehingga dan lebih percaya diri dalam menyampaikan ide maupun pendapatnya sehingga dapat mengembangkan kompetensi dan kemampuan berpikir kreatif secara optimal, 2) guru hendaknya menerapkan model pembelajaran inovatif sesuai dengan karakteristik siswa dan materi pembelajaran untuk meningkatkan kompetensi dan 
kreativitas siswa dalam proses pembelajan, 3) bagi sekolah lebih bijak dalam memilih model serta media pembelajaran yang dapat meningkatkan kreativitas dan kompetensi pengetahuan siswa dan 4) bagi peneliti lain hasil penelitian ini dapat dijadikan pedoman untuk melakukan penelitian terkait dengan model pembelajaran, media pembelajaran, dan penelitian tentang variabel yang sama..

\section{DAFTAR PUSTAKA}

Adnyana, I. K. W. S., dkk. 2017. "Pengaruh Model Pembelajaran Kooperatif Tipe Talking Stick Terhadap Kompetensi Pengetahuan IPA Siswa Kelas V SD Gugus Kpten Kompyang Sujana”. Volume 5, Nomor 3 (hlm 1-11).

Agung, A. A. G. 2014. Metode Penelitian Pendidikan. Yogyakarta: Aditya Media Publishing.

Delianti, P. I., dkk. 2018. "Pengaruh Model Pembelajaran Student Facilitator and Explaining terhadap Hasil Belajar Simulasi Digital”. Jurnal Vokasional Teknik Elektronika \& Informatika, Volume 6, Nomor 1 (hlm 115-122).

Kurniasih, I. dan B. Sani 2015.Ragam Model Pembelajaran Untuk Peningkatan Profesionalitas Guru.Yogyakarta: Kata Pena.

Samatowa, U. 2018. Pembelajaran IPA di Sekolah Dasar. Jakarta: PT Indeks.

Sani, R. A. 2015. Pembelajaran Saintifik untuk Implementasi Kurikulum 2013. Jakarta: PT Bumi Aksara.

Santi, V. P., dkk. 2017. "Pengembangan Panduan Mind Mapping untuk Meningkatkan Keterampilan Belajar”. Jurnal Program Studi Bimbingan dan Konseling, Volume 5, Nomor 2 (hlm 96-100).

Shoimin, A. 2017.68 Model Pembelajaran Inovatif dalam Kurikulum 2013.Yogyakarta: Ar-ruzz Media.

Sormin, M. A. 2016. "Upaya Meningkatkan Kreativitas Belajar Matematika Siswa Melalui Pembelajaran Cooperatif Learning Tipe Jigsaw di SMK Negeri 1 Padangsidimpuan”.Jurnal Eksakta, Volume 2, Nomor 1 (hlm 19-27).

Swadarna, D. 2013. Mind Mapping dalam Kurikulum Pembelajaran. Jakarta: Kompas Gramedia.

Trianto. 2012. Model Pembelajaran Terpadu. Jakarta: Bumi Angkasa.

Yaumi, M. 2014. Prinsip-Prinsip Desain Pembelajaran Disesuaikan dengan Kurikulum 2013. Jakarta: Kencana Prenadamedia Group. 